\title{
TEACHER TRAINERS' ATTITUDE TOWARDS USING TECHNOLOGIES
}

\author{
S. VENKATARAMAN \& S. MANIVANNAN
}

Assistant Professor, Department of Education, Annamalai University, Annamalai Nagar, Tamil Nadu, India

\begin{abstract}
This study was conducted to find out the Teacher Trainers'Attitude towards Using Technologies, for this study, Normative Survey method was adopted. Random sampling technique was used in the selection of the sample for 200 Teacher Trainers from Cuddalore district of Tamilnadu, India. The tool used in this study is the Attitude towards Using Technologies Scale (Mustafa, 2012). It is found that the Teacher Trainers have good Attitude towards Using Technologies.
\end{abstract}

KEYWORDS: Teacher Trainers, Attitude \& Using Technologies

Received: Oct 25, 2018; Accepted: Nov 15, 2018; Published: Dec 02, 2018; Paper Id.: IJEEFUSOCT20186

\section{INTRODUCTION}

Teaching and innovation are two key components having a significant job in the Society. The point of the Teaching is to assist the general population with what we know. Innovation causes people to take points of interest of their insight and aptitudes all the more viably and productively. Innovation is the control which connects among science and its applications. The term "Technologies" is much of the time utilized along instructional media and instructional materials to mean every one of the materials and gear that are utilized to. The utilization of Technologies has a few focal points.

Sevinc Mert Uyangor (2010) determined the attitudes of prospective teachers of Secondary Mathematics Education toward Technologies. It was observed that the instructor's positive attitudes toward the course, and group works contributed to that development and to the success of the prospective teachers in their activities. Morgan, A. Christian et al., (2011) imply that teachers with positive attitudes and self-efficacy for adopting the model may struggle to implement collaboration due to a lack of time and access to technology. Howley, Aimee et al., (2011) compared rural with non-rural teachers, revealing that the rural teachers had more positive attitudes toward technology integration. Charles B. Andoh (2012) reviewed personal, institutional and technological factors that encourage teachers' use of technology in teaching and learning processes. DeCuir, Alvin F., Jr. (2012) found that the linear combination of teacher attitudes toward technology, teachers' experience, age, and gender was not significantly related to technology usage. Upasana Singh (2013) showed that there is critical connection between capability of in-administration instructors and their disposition towards innovation combination and between recurrence of use of innovation in class room guidance and the attitude of pre-administration educators towards innovation mix

Celik, Vehbi and Yesilyurt, Etem (2013) tested the effect levels among the latent variables of attitude to technology, perceived computer self-efficacy, computer anxiety and the attitude toward doing computer supported education. The significant finding of this study is that attitude to technology, perceived computer self-efficacy and 
computer anxiety are important predictors of teacher candidates' attitude towards using computer supported education. Hayes, Elisabeth et al., (2013) identified the gaming practices of freshmen undergraduate teacher education students. Teo, Timothy and Zhou, Mingming (2014) examined the factors that an influence higher education students' intention to use technology.

Celik, Vehbi and Yesilyurt, Etem (2013) tried the impact levels among the inert factors of frame of mind to innovation, saw computer self-adequacy, computer nervousness and the mentality toward doing computer bolstered instruction. The important finding of this investigation is that frame of mind to innovation, computer self-viability and computer anxiety are significant indicators of teacher candidates' disposition toward utilizing computer supported training. Hayes, Elisabeth et al., (2013) recognized the gaming practices of first year recruits undergrad instructor training students. Teo, Timothy and Zhou, Mingming (2014) analyzed the variables that an impact advanced education understudies' goal to utilize innovation.

\section{NEED AND IMPORTANCE OF THIS STUDY}

An immediate relationship exists between expert advancement and Trainees' accomplishment, and the last is additionally legitimately identified with instructor fulfillment. Instructor Trainers and Institutes that esteem proficient advancement encourage a positive situation. At the point when understudies are gaining astounding scholastic and social ground, Teacher Trainers feel the prizes of their calling. When the Institutes provides meaningful and effective professional development to their Teacher Trainers, high Attitude towards Using Technologies and overall school success can be assured. Hence the investigator has taken this for study.

\section{OBJECTIVES OF THIS STUDY}

The present study has the following objectives:-

- To find out the Teacher Trainers' level of Attitude towards Using Technologies.

- To find out whether there is any significant difference between Arts and Science, Male and Female, rural and urban, $\mathrm{OC} / \mathrm{BC} / \mathrm{MBC} / \mathrm{SC} / \mathrm{ST}$ and below 10 years experienced and above 10 years experienced Teacher Trainers in their Attitude towards Using Technologies.

\section{HYPOTHESES OF THIS STUDY}

Investigator of this study formulated suitable null hypotheses.

\section{METHOD OF STUDY}

In the present study, Normative Survey method is adopted.

\section{SAMPLE OF THIS STUDY}

Random sampling technique is used in the selection of the sample for 200 Teacher Trainers from Cuddalore district of Tamilnadu, India

\section{TOOL USED IN THIS STUDY}

The tool used in this study is the Attitude towards Using Technologies Scale (Mustafa, 2012). 


\section{DESCRIPTIVE ANALYSIS}

To find out the Teacher Trainers,' Attitude towards Using Technologies the mean and S.D have been calculated.

Table 1: The Mean and Standard Deviation of Teacher Trainers' Attitude towards Using Technologies

\begin{tabular}{|c|c|c|c|c|}
\hline Demographic Variable & Sub Sample & N & Mean & SD \\
\hline \multirow{2}{*}{ Group } & Arts & 89 & 145.98 & 27.34 \\
\cline { 2 - 5 } & Science & 111 & 154.93 & 24.81 \\
\hline \multirow{2}{*}{ Gender } & Male & 106 & 142.21 & 27.45 \\
\cline { 2 - 5 } & Female & 94 & 158.33 & 22.63 \\
\hline \multirow{2}{*}{ Locality } & Rural & 105 & 149.64 & 27.36 \\
\cline { 2 - 5 } & Urban & 95 & 152.55 & 25.1 \\
\hline \multirow{3}{*}{ Community } & OC & 52 & 160 & 24.08 \\
\cline { 2 - 5 } & BC & 51 & 144.35 & 25.31 \\
\cline { 2 - 5 } & MBC & 54 & 153.24 & 26.46 \\
\cline { 2 - 5 } & SC/ST & 43 & 144.11 & 26.26 \\
\hline \multirow{2}{*}{ Experience } & below 10years & 136 & 155.12 & 24.2 \\
\cline { 2 - 5 } & above 10years & 64 & 144.41 & 28.13 \\
\hline \multirow{2}{*}{ Total } & & $\mathbf{2 0 0}$ & $\mathbf{1 5 1 . 3 3}$ & $\mathbf{2 6 . 3 2}$ \\
\hline
\end{tabular}

\section{Total Sample}

It is inferred from the above table that the calculated mean score of $t$ Total sample indicates that the Teacher Trainers have positive Attitude towards Using Technologies.

\section{DIFFERENTIAL ANALYSIS}

\section{Null Hypothesis 1}

To test the Null hypothesis ' $t$ ' value is calculated.

Table 2: Arts and Science Teacher Trainers Attitude towards Using Technologies

\begin{tabular}{|c|c|c|c|c|c|}
\hline Group & N & Mean & SD & T-value & Significance at 0.05 Level \\
\hline Arts & 89 & 145.98 & 27.34 & \multirow{2}{*}{2.71} & Significant \\
\hline Science & 111 & 154.93 & 24.81 & & \\
\hline
\end{tabular}

From the above table, since the ' $\mathrm{t}$ ' value is significant at 0.05 level, the framed Null hypothesis is rejected and it is concluded that there is significant difference between Arts and Science Teacher Trainers with respect to their Attitude towards Using Technologies.

\section{Null Hypothesis 2}

To test the above Null hypothesis ' $t$ ' value is calculated.

Table 3: Male and Female Teacher Trainers Attitude towards Using Technologies

\begin{tabular}{|c|c|c|c|c|c|}
\hline Gender & $\mathbf{N}$ & Mean & SD & T-Value & Significance at 0.05 Level \\
\cline { 1 - 4 } Male & 106 & 142.21 & 27.45 & \multirow{2}{*}{5.12} & Significant \\
\hline Female & 94 & 158.33 & 22.63 & & \\
\hline
\end{tabular}

From the above table, since the ' $\mathrm{t}$ ' value is significant at 0.05 level, the framed Null hypothesis is rejected and it is concluded that there is significant difference between Male and Female Teacher Trainers with respect to their Attitude towards Using Technologies. 


\section{Null Hypothesis 3}

To test the Null hypothesis ' $t$ ' value is calculated.

Table 4: Rural and Urban School Teacher Trainers Attitude towards Using Technologies

\begin{tabular}{|c|c|c|c|c|c|}
\hline Locality & N & Mean & SD & T-Value & Significance at 0.05 Level \\
\cline { 1 - 4 } Rural & 105 & 149.64 & 27.36 & \multirow{2}{*}{1.12} & Not significant \\
\hline Urban & 95 & 152.55 & 25.1 & & \\
\hline
\end{tabular}

From the above table, since the ' $t$ ' value is not significant at 0.05 level, the framed Null hypothesis is accepted and it is concluded that there is no significant difference between rural and urban Teacher Trainers with respect to their Attitude towards Using Technologies.

\section{Null Hypothesis 4}

To test the Null hypothesis ' $F$ ' value is calculated.

Table 5: Significance of Difference among the Sub-Samples of Community with Respect to their Attitude Towards Using Technologies

\begin{tabular}{|c|c|c|c|c|c|}
\hline & Sum of Squares & df & Mean Square & F & Significance at 0.05 Level \\
\hline Between Groups & 9046.990 & 4 & 2261.748 & & \multirow{2}{*}{ Significant } \\
\cline { 1 - 4 } Within Groups & 100157.885 & 195 & 513.630 & & \\
\hline Total & 109204.875 & 199 & & & \\
\hline
\end{tabular}

The above table indicates that the calculated ' $F$ ' value 4.523 is higher than the Table value at 0.05 level of significance. Hence it is concluded that, there is significant difference among OC, BC, MBC, SC/ST Teacher Trainers in their Attitude towards Using Technologies.

\section{Null Hypothesis 5}

To test the Null hypothesis ' $t$ ' value is calculated.

Table 6: Significance of Difference between Below 10yrs and Above 10 yrs Experience with Respect to Their Attitude towards Using Technologies

\begin{tabular}{|c|c|c|c|c|c|}
\hline Locality & $\mathbf{N}$ & Mean & SD & T-Value & Significance at 0.05 Level \\
\hline below 10years & 136 & 155.12 & 24.2 & \multirow{2}{*}{3.21} & \multirow{2}{*}{ Significant } \\
\hline above 10years & 64 & 144.41 & 28.13 & & \\
\hline
\end{tabular}

From the above table, since the 't' value is significant at 0.05 level, the above Null hypothesis is rejected and it is concluded that there is significant difference between below 10 years and above 10 years experience with respect to their Attitude towards Using Technologies.

- The Teacher Trainers are having positive Attitude towards Using Technologies.

- There is significant difference between Arts and Science, Male and Female, below 10years and above 10 years experience Teacher Trainers with respect to their Attitude towards Using Technologies.

- There is no significant difference between rural and urban Teacher Trainers with respect to their Attitude towards Using Technologies. 
- There is significant difference among OC, BC, MBC, SC/ST Teacher Trainers in their Attitude towards Using Technologies.

\section{RECOMMENDATIONS}

In light of the findings the following are recommended: Except locality all other statistical factors indicates impact, thus these separations ought to be considered while confining educator preparing educational modules. Attitude towards Using Technologies is the significant factor to grow great residents; henceforth Teacher Trainers ought to grow positive attitude towards Using Technologies. Experts should require exertion to support this positive nature and upgrade it among the Teacher Trainers. Instructor teachers should take note of the variables that got low Attitude towards Using Technologies scores. When overseeing young Teacher Trainers, need to feature the one of a kind parts of training that may energize low Attitude towards Using Technologies levels. Young Teacher Trainers may need additional assistance in dealing with community pressures and teacher load concerns. When supervising young Teacher Trainers, teacher educators need to highlight the unique aspects of teaching that may encourage low Attitude towards Using Technologies levels. Coping with inadequate school facilities, adjusting to a heavy teaching load, getting along with other Teacher Trainers and the principal, and handling community pressures are areas that may need to be addressed in the pre service preparation and in service programs for young Teacher Trainers.

\section{CONCLUSIONS}

The future Teacher Trainers must remember that each Teacher Trainers' approach is influencing understudy's logic, consequently Teacher Trainers ought to be fair in the entirety of his exercises in order to impact the understudies emphatically. An instructor guidance program (in-organization) could be offered to focus on components that got low Attitude towards Using Technologies scores.. Instructor teachers ought to recognize those components that can be influenced by educator input, for example, taking care of network weights and coexisting with directors and other Teacher Trainers. Subsequently these are to be steered to redesign outlook towards Using Technologies. Progressively escalated investigations in ordinary way ought to be led among the Teacher Trainers to pass judgment on their progressions. Hence, these are to be addressed to enhance attitude towards Using Technologies.

\section{REFERENCES}

1. Celik, Vehbi and Yesilyurt, Etem (2013) Attitudes to Technology, Perceived Computer Self-Efficacy and Computer Anxiety as Predictors of Computer Supported Education, Computers \& Education, 60,1,148-158.

2. Charles B. Andoh (2012) Factors influencing teachers' adoption and integration of information and communication technology into teaching: A review of the literature, International Journal of Education and Development using Information and Communication Technology, 8, 1, 136-155.

3. Chowdhury, P. (2018). Ethical Dimensions in Teaching and Teacher Education: A Review. IMPACT: International Journal of Research in Humanities, Arts and Literature (IMPACT: IJRHAL) ISSN (P), 2347-4564.

4. DeCuir, Alvin F., Jr. (2012) The Relationship between Teachers' Attitudes toward Technology and Technology Use, Ed.D. Dissertation, Walden University.

5. Fatima, I., \& Alias, I. N. (2017). A Comparative Study of Emotional Maturity of Teacher Trainees Inbareilly District, Uttar Pradesh. IMPACT: International Journal of Research in Humanities, Arts and Literature (IMPACT: IJRHAL) ISSN (P), 23474564. 
6. Hayes, Elisabeth et al., (2013) The Gamer Generation Teaches School: The Gaming Practices and Attitudes towards Technology of Pre-Service Teachers, Journal of Technology and Teacher Education, 212 154-177.

7. Howley, Aimee et al., (2011) Rural Elementary School Teachers' Technology Integration, Journal of Research in Rural Education, 26, 9.

8. Morgan, A. Christian et al., (2011) Enhancing Collaboration among Math and Career and Technical Education Teachers: Is Technology the Answer?, Journal of Career and Technical Education, 26,2,77-89.

9. PP, S. (2017). Job Satisfaction of Women Teachers With Special Reference to Malappuram District. International Journal of Human Resources Management (IJHRM), 6(6), 1-8.

10. Sevinc Mert Uyangor (2010) The Attitudes of the Prospective Mathematics Teachers towards Instructional Technologies and Material Development Course, Turkish Online Journal of Educational Technology9, 1, 213-220.

11. Teo, Timothy and Zhou, Mingming (2014) Explaining the Intention to Use Technology among University Students: A Structural Equation Modeling Approach, Journal of Computing in Higher Education, 26, 2,124-142.

12. Upasana Singh (2013) Technology Integration in Teacher Education: an Infusion or a Delusion, Journal of Arts, Science \& Commerce, 4, 3, 147-154. 